\title{
Genetic evaluation in the honey bee considering queen and worker effects - A BLUP-Animal Model approach*
}

\author{
Kaspar BIENEFELD ${ }^{\mathrm{a}}$, Klaus EHRHARDT ${ }^{\mathrm{a}}$, Friedrich REINHARDT ${ }^{\mathrm{b}}$ \\ ${ }^{a}$ Institute of Bee Research, Friedrich Engels Str. 32, 16540 Hohen Neuendorf, Germany \\ ${ }^{\mathrm{b}}$ Ostpreußenweg 8, 27308 Kirchlinteln, Germany
}

Received 18 August 2005 - Accepted 16 June 2006

\begin{abstract}
The estimation of breeding value for the honey bee is markedly more difficult than for other agricultural animals as colony traits in honey bees are the expression of the combined activities of the queen and workers. Recent studies have shown strong negative genetic correlations between the contributions of both queens and workers to economically important traits (e.g. honey production). The most advantageous method currently available for evaluating breeding values in other animals, the Best Linear Unbiased Prediction (BLUP)-Animal Model, has been adapted to the peculiarities of honey bee genetics and reproduction. This method considers maternal (queen) effects using all available records of relatives and weights these so as to obtain the most accurate prediction of the genotype. It simultaneously considers environmental effects, genetic merit of mates and contemporarily tested colonies, and estimates the breeding values for queen and worker effects on colony traits for each queen.
\end{abstract}

Apis mellifera / breeding value / genetic response / honey production / maternal effects / BLUP-Animal Model

\section{INTRODUCTION}

Several distinctive genetic and reproductive peculiarities in the honey bee make the breeding of this species difficult. While several complex breeding strategies have been developed which take these peculiarities into account (Crow and Roberts, 1950; Mackensen and Nye, 1966; Ruttner, 1968; Böger, 1969; Cale and Rothenbuhler, 1975; Rinderer, 1977; Page and Laidlaw, 1982; Milne, 1985; Oldroyd et al., 1985; Kulincevic, 1986; Moritz, 1986; Szabo and Lefkowitch, 1987; Bienefeld, 1994; Harbo, 1996), the breeding evaluation of the honey bee is not as advanced as in other agricultural species (Willam, 1991). Most traits are determined by both the animal's genes and the environment in which it is kept, but the breeding value is solely determined by its genes.

Corresponding author: K. Bienefeld, Kaspar.Bienefeld@rz.hu-berlin.de

* Manuscript editor: Walter S. Sheppard
The environmental effect on the animal is corrected for as effectively as possible by comparing the measurements of the animal and its relatives (animals with partly the same genes) in different locations and years to the measurements of other (unrelated) animals. Since only genes and not environmental influences are passed on to the next generation, genetic evaluation is essential for every breeding programme. An animal can have as many breeding values as there are traits to be measured.

To estimate the breeding value using measurements of related animals, an accurate estimate of the genetic relatedness (degree of genetic conformity) between the informants and the animal in question is necessary. This is less complex in other species $(0.5$ between full sibs, 0.25 for half sibs and 0.5 between parent and offspring, etc.), but due to the honey bee queen's multiple mating habits and the existence of haploid males, calculations are much more complex. Within a single colony, the 
genetic relationship can vary between 0.25 and (without inbreeding) 0.75 (Crow and Roberts, 1950; Polhemus et al., 1950; Laidlaw and Page, 1984).

However, the main methodological problem is that the colony's performance and behaviour both result from the interaction between the queen and worker bees. The workers collect the nectar and engage in a specific defence behaviour, but the queen also influences honey production and the colony's behaviour. A comparable situation is observable in mammals where the phenotypic expression of maternally influenced traits in the progeny, such as birth and weaning weight, are influenced by, for example, the ability of the dam to provide enough milk and a suitable environment. Thus, the dam contributes to the performance of the progeny in two ways: firstly, through her direct genetic effects (genes) passed to the progeny and secondly, through her ability to provide a suitable environment. In the honey bee, maternally influenced traits can be defined as the sum of unknown non-genetic queen influences, such as the quality and quantity of eggs produced, pheromone production, etc. on traits measured in the offspring workers. It is hardly possible to measure these queen effects directly in the queens themselves, but only via the impact on their progeny (colony performance or behaviour). Their impact on worker bees is strictly environmental; however, the queen's ability to lay enough eggs of sufficient size, produce pheromones, etc. is both genetically and environmentally determined.

Willham (1963) developed a general model which allows for a separate estimation of the heritabilities for the direct and maternal effects and the genetic correlation between them. The genetic correlations are important because genes may affect both maternal influence on and the direct effects of the progeny. Willham's approach is based on the measurements of offspring traits (e.g. growth) of differently related animals (full sibs, maternal or paternal half sibs, cousins, etc.) which exhibit different genetic relations between the mothers and offspring, allowing a statistical separation of maternal and direct effects on a trait.

This approach can be adapted to the peculiarities of the honey bee (Chevalet and
Cornuet, 1982). Calculations using a large data set of performance test results from Apis mellifera indicated moderate heritabilities for worker and queen bee influence on various colony characters, such as honey production, defence behaviour and calmness during inspection (Bienefeld and Pirchner, 1990). However, in common with results from other agricultural animals (Robinson, 1981), the honey bee also displayed a clear negative genetic correlation between direct (worker) and maternal (queen) effects on these traits (Bienefeld and Pirchner, 1990). Lerner (1950) pointed out that genetic correlations between two characters would eventually become negative if selection were to be applied to both traits simultaneously. Those pleiotropic genes that affect both characters in the desired direction would be acted upon strongly by selection and brought towards fixation, whereas pleiotropic genes that affect one characteristic favourably and the other adversely would be influenced much less by selection and would remain at intermediate frequencies. The negative consequence of the negative correlation between maternal and direct effects is that it strongly impedes selection response (Willham, 1963; Foulley and Lefort, 1978; Roehe and Kennedy, 1993). Hanrahan (1976) derived that if the ratio $h_{\text {direct }} / h_{\text {maternal }}(h=$ square root of the heritability) is less than the absolute value of the negative genetic correlation, then selection response will actually run in the direction opposite to that which was intended.

Chevalet and Cornuet (1987) developed a selection index for one trait and van Engelsdorf and Otis (2000) developed an index for several traits for honey bees. Bienefeld and Pirchner (1991) meanwhile derived a selection index for several traits which simultaneously considers queen and worker effects. However, the use of selection indices is becoming less common, as environmental influences as well as differences in the genetic levels of the mating partners and the simultaneously tested animals in the testing station can only be insufficiently corrected for.

Best linear unbiased prediction (BLUP) has become the most widely accepted method for genetic evaluation of domestic livestock. The most advanced procedure currently available is 
the BLUP-Animal Model (Henderson, 1988). Traditional methods of genetic evaluation use only limited information (own performance and performance of sisters) and do not include an adjustment for the level of contemporarily tested animals or for the merit of the mate of an animal. In these methods it is assumed that all mates and all contemporarily tested animals are a random sample of the population, and to the extent that this assumption is incorrect, bias could enter into the evaluation. BLUP is, in simple terms, a simultaneous evaluation of animals in which the genetic merit of all relatives plus the animal's own performance are used to estimate the animal's genetic merit.

The objective of this study is to extend the BLUP-Animal Model for the use of genetic evaluation in the honeybee.

\section{METHOD OF CALCULATION}

\subsection{The BLUP-Animal Model methodology considering maternal effects}

If the BLUP-Animal Model methodology on the biology of honey bees is to be used, the combined influences of the queen and workers on the characteristics of a colony and the negative genetic correlation between both effects have to be considered. Quaas and Pollak (1981) first developed an approach which takes the exertion of maternal influence into account. This was adapted to the genetic peculiarities of the honey bee as follows:

$$
\mathrm{y}=\mathrm{Xb}+\mathrm{Z}_{1} \mathrm{u}_{1}+\mathrm{Z}_{2} \mathrm{u}_{2}+\mathrm{e}
$$

where

$\mathrm{y}=\mathrm{a}$ vector of records/traits of the colonies (e.g. honey production, defence behaviour),

$\mathrm{b}=\mathrm{a}$ vector of fixed year/beekeeper/location effects,

$\mathrm{u}_{1}=\mathrm{a}$ vector of random worker (direct) effects, $\mathrm{u}_{2}=\mathrm{a}$ vector of random queen (maternal) effects,

$\mathrm{e}=\mathrm{a}$ vector of random residual effects,

$\mathrm{X}=\mathrm{a}$ known incidence matrix relating the observations to the corresponding environment (year/beekeeper/location),
$\mathrm{Z}_{1}=\mathrm{a}$ known incidence matrix relating the observations to corresponding worker effects, $\mathrm{Z}_{2}=\mathrm{a}$ known incidence matrix relating the observations to the corresponding queen effects. Solutions were obtained from the following mixed model equations:

$$
\begin{gathered}
\left(\begin{array}{ccc}
\mathrm{X}^{\prime} \mathrm{X} & \mathrm{X}^{\prime} \mathrm{Z}_{1} & \mathrm{X}^{\prime} \mathrm{Z}_{2} \\
\mathrm{Z}^{\prime}{ }_{1} \mathrm{X} & \mathrm{Z}^{\prime}{ }_{1} \mathrm{Z}_{1}+\mathrm{A}^{-1} \alpha_{1} & \mathrm{Z}^{\prime}{ }_{1} \mathrm{Z}_{2}+\mathrm{A}^{-1} \alpha_{2} \\
\mathrm{Z}_{2}^{\prime}{ }_{2} \mathrm{X} & \mathrm{Z}_{2}^{\prime}{ }_{2} \mathrm{Z}_{1}+\mathrm{A}^{-1} \alpha_{2} & \mathrm{Z}_{2}^{\prime} \mathrm{Z}_{2}+\mathrm{A}^{-1} \alpha_{3}
\end{array}\right) . \\
\\
\left(\begin{array}{c}
\mathrm{b} \\
\mathrm{u}_{1} \\
\mathrm{u}_{2}
\end{array}\right)=\left(\begin{array}{c}
\mathrm{X}^{\prime} \mathrm{y} \\
\mathrm{Z}^{\prime}{ }_{1} \mathrm{y} \\
\mathrm{Z}^{\prime}{ }_{2} \mathrm{y}
\end{array}\right)
\end{gathered}
$$

where

$$
\left(\begin{array}{ll}
\alpha_{1} & \alpha_{2} \\
\alpha_{2} & \alpha_{3}
\end{array}\right)=\left(\begin{array}{ll}
\sigma_{1}^{2} & \sigma_{12}^{2} \\
\sigma_{12}^{2} & \sigma_{2}^{2}
\end{array}\right)^{-1} \cdot \sigma_{e}^{2}
$$

with

$\sigma_{1}^{2}=$ additive genetic variance for worker effects,

$\sigma_{2}^{2}=$ additive genetic variance for queen effects,

$\sigma_{12}^{2}=$ additive genetic covariance between worker and queen effects,

$\sigma_{e}^{2}=$ residual error variance,

$\mathrm{A}^{-1}=$ inverse of the additive genetic relationship matrix.

The matrix which indicates the additive genetic relationship among individuals is called the numerator relationship matrix $\mathrm{A}$, which is symmetric, and its diagonal element for animal $i$ is equal to $1+F_{i}$ where $F_{i}$ is the inbreeding coefficient of animal $i$ (Wright, 1922). The diagonal elements represent twice the probability that two gametes taken at random from animal $i$ will carry identical alleles by descent. The off-diagonal elements constitute the numerator of the coefficient of relationship between animals $i$ and $j$.

However, for solving the mixed model equations (2), it is not the relationship matrix A which is required, but rather its inverse, $\mathrm{A}^{-1}$. Calculation of the inverse of this matrix becomes cumbersome if the size of the pedigree increases. Henderson (1976a) and Dempfle (1989) derived a very efficient algorithm to generate the inverse of the relationship matrix A directly via the decomposition

$$
\mathrm{A}^{-1}=\mathrm{M}^{-1} \cdot \mathrm{D}^{-1} \cdot\left(\mathrm{M}^{\prime}\right)^{-1},
$$


where $\mathrm{M}^{-1}$ is a lower triangular matrix with all 1's in the diagonal and with the only nonzero elements of the ith-row being -0.5 for the columns corresponding to known parents, while $\mathrm{D}$ is a diagonal matrix which is dependent on the pedigree information.

The definition of both matrices will be subsequently adapted to the very specific situation of pedigree recording in honey bee breeding in order to maintain the merits and ease of use of the well-established theory above.

\subsection{Adaptation of the BLUP-Animal Model to the peculiarities of the honey bee}

The principle of our maternal trait model does not differ from other BLUP-Animal Models that take maternal effects into account. The general theory and details of application of these are fully described by Mrode (1996). However, one important modification is necessary for the evaluation of honey bees as the genetic relationships within the honey bee population are much more complex. Genetic evaluation using the BLUP model is heavily dependent on the genetic covariance among individuals for both higher accuracy and unbiased results.

Genetic relationships and inbreeding in the honey bee strongly depend on the breeding scheme and mating system. The mode of calculating the relationship matrix was adapted to the situation in Germany (this revised formula is also applicable to breeding schemes in other countries, however). Here, the queens are mated by drones of known descent in isolated mating stations (mostly islands) or by artificial insemination. In the mating station, several queens provide the drones. These drone-producing queens are all daughters of a single breeding queen. Only this breeding queen is listed in the pedigree. Polemus et al. (1950) pointed out that the haploid drone can be considered as a random sample of identical gametes from his female parent. Consequently, the drone-producing queen corresponds to the sire in ordinary diploid species. Since more than one queen is used for mating, the paternal descent is a mixture of semen from sis- ters. Bienefeld et al. (1989) showed that in this case the average genetic relationship between two individuals (or "average individuals" in the case of workers) depends on the weighted probability descending from the same drone, from different drones of the same queen or from different drones of different but related queens. In regular mating systems, where the number of drone-producing queens and the degree of their genetic relatedness in the mating station is similar year after year, these coefficients of relationship can be expressed as a function of the average number of drones $d$ a queen mates with and the number of droneproducing queens $q$ (Bienefeld et al., 1989). To recapitulate this result, the average relatedness in full sibs $f S$ (identical mother mated on the same mating station), and the corresponding value in half sibs $h S$ (different mother, but descended from drones from the same mating station) are defined by

$$
\begin{aligned}
& f S(q, d)=\frac{2 q+d+q d-1}{q+d+3 q d-1} \\
& h S(q, d)=\frac{2 q+3 d+q d-2}{4(q+d+3 q d-1)} .
\end{aligned}
$$

These estimates are not much affected by realistic deviations from these assumptions (Bienefeld et al., 1989). The described mating scheme has been used in some countries for several decades, but the procedure of estimating the average relationship can be adapted to other honey bee breeding schemes as well.

To address cases in which pedigree information is only available on the male side, Henderson (1976b) developed the father - maternal grandfather - approach, in which the same method of calculation is used, but the corresponding coefficients in $\mathrm{M}$ and $\mathrm{D}$ have to be altered. Since in the honey bee there is clear pedigree information on the female side (mother, mother of drone-producing queens) only, this approach initially seems to be more appropriate. However, if only the mother of the drone-queens is considered in the pedigree (and not the drone-producing queens themselves), possible genetic relationships resulting from their paternal descent are neglected. This results in an underestimation of genetic relatedness, and consequently, in a less accurate genetic evaluation. 
To solve this problem, a dummy father is inserted into the pedigree for each droneproducing sister group. The maternal descent of these dummy fathers is the mother of the drone-producing queens; paternally, they themselves are also descended from a dummy father, which has to be newly coded and inserted into the pedigree. The advantage of this method is that complete pedigree information is now available for every queen and average worker bee on the paternal side in each generation as well. Since these newly coded fathers do not correspond to a normal single individual, but to a sample of gametes from a related sibling group, the genetic relationship of the offspring also differs from the normal breeding situation in other animals

Whereas the female parent-offspring relationships are identical with other species, the coefficient characterising the paternal gene flow needs to be modified. The paternal and maternal flow of genes also determines the genetic relationship between offspring. A problem arises in the honey bee in that the transmission of paternal genes results in different genetic relationships in the offspring depending on whether two individuals share the same mother or not. If two individuals have different mothers (paternal half sibs), they cannot share identical paternal genes (that means, descending from the same drone). If two individuals have the same father and mother, $1 / d$ ( $d=$ average number of drones mated with the queens) of these offspring share, on average, $100 \%$ identical paternal genes.

To solve the problem of different paternal gene transmission, Bienefeld and Reinhardt (1995) suggested adjusting for the underestimation of genetic relatedness in full sibs and the overestimation of genetic relatedness in paternal half sibs by using correcting factors in the corresponding off-diagonal elements in D. However, D then becomes a diagonal-blockmatrix, and the size of the units to be inverted are of the order of magnitude of halfsibling groups. Consequently, this approach is less suitable for larger data sets.

Much more efficient from a computational point of view is to keep $\mathrm{D}$ as a diagonal matrix and to parameterise the path coefficient in $\mathrm{M}$ between the dummy father and its offspring in such a way that it minimises the sum of least squares deviations of the estimated genetic relationships and their theoretical assumptions concerning the average relatedness within fulland half-sibling groups. This procedure gives an estimation of the average path coefficient $p$

$$
\begin{aligned}
p(q, d) & =\frac{1}{2} \sqrt{2(f S+h S)-\frac{1}{2}} \\
& =\frac{1}{2} \sqrt{\frac{9 q+6 d+2 q d-5}{2(q+d+3 q d-1)}},
\end{aligned}
$$

between a dummy father and its offspring which is generally unequal to 0.5 .

At present an average path paternal coefficient of $p(8,12)=0.367$ is used, which is deduced from the preliminary fixing of an average of $q=8$ drone-producing queen colonies, and $d=12$ effective drones per mated queen stemming randomly from these colonies. Figure 1 demonstrates that the slopes of the relatedness functions are very smooth within the parameter range of interest.

From this concept of a dummy father with paternal path coefficient $p \neq 0.5$ follows, that other than in the case of mammals, the breeding value $u_{i}$ of an offspring is calculated from the corresponding values of its parents $(\mathrm{s}=$ sire, $d=$ dam) with Mendelian sampling $\mathrm{m}_{\mathrm{i}}$ by means of

$$
\mathrm{u}_{\mathrm{i}}=0.5 \mathrm{u}_{\mathrm{d}}+\mathrm{pu}_{\mathrm{s}}+\mathrm{m}_{\mathrm{i}}
$$

which gives an additional term in calculating the variance of the Mendelian sampling,

$$
\begin{aligned}
\operatorname{var}\left(\mathrm{m}_{\mathrm{i}}\right)= & \operatorname{var}\left(\mathrm{u}_{\mathrm{i}}\right)-\operatorname{var}\left(p \mathrm{u}_{\mathrm{s}}\right)-\operatorname{var}\left(0.5 \mathrm{u}_{\mathrm{d}}\right) \\
& -2 \operatorname{cov}\left(p \mathrm{u}_{\mathrm{s}}, 0.5 \mathrm{u}_{\mathrm{d}}\right) \\
= & \sigma_{u}^{2}\left[\left(1+F_{i}\right)-p^{2} a_{s s}\right. \\
& \left.-0.25 a_{d d}-p a_{s d}\right] \\
= & \sigma_{u}^{2}\left[1-p^{2}\left(1+F_{s}\right)\right. \\
& \left.-0.25\left(1+F_{d}\right)+(1-2 p) F_{i}\right]
\end{aligned}
$$

whereas $a_{s s}=1+F_{s}, a_{d d}=1+F_{d}$ and $a_{s d}=$ $2 F_{i}$ are elements of the numerator relationship matrix A. 


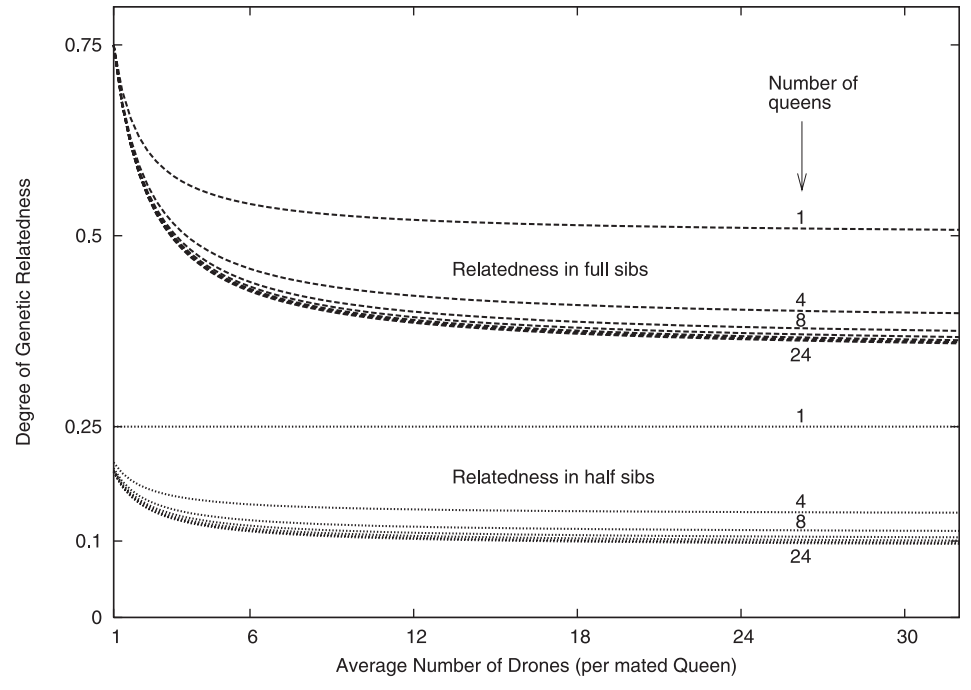

Figure 1. Genetic relatedness in full and half sibs in the honey bee [descending from varying numbers of related droneproducing queens (1-24) and of drones with which a queen mates (1-32)].

The elements of the diagonal matrix $\mathrm{D}=\operatorname{diag}\left(\operatorname{var}\left(\mathrm{m}_{\mathrm{i}}\right) / \sigma_{u}^{2}\right)$ are then derived by

Pedigree status $\quad$ Elements of matrix D

neither parent is known

1

either "sire" $(s)$ or

$1-p^{2}\left(1+F_{s}\right)$

"dam" $(d)$ is known

$1-0.25\left(1+F_{d}\right)$

both parents are known

$1-p^{2}\left(1+F_{s}\right)-0.25\left(1+F_{d}\right)+(1-2 p) F_{i}$

which yields the classical formula $1-0.25(1+$ $\left.F_{s}\right)-0.25\left(1+F_{d}\right)$ in the conventional case where $p=0.5$.

\section{THE ADVANTAGE OF THE NEW CONCEPT OF GENETIC EVALUATION IN THE HONEY BEE}

The prediction of breeding values constitutes an integral part of most breeding programmes for genetic improvement. Whereas breeding programmes are very complex in the honey bee, the standard of genetic evaluation is not equivalent to its economic and ecological importance. Due to mating behaviour and highly complicated genetics, there are insufficient modern approaches for this species. Modern concepts of genetic evaluation cannot be directly used for the honey bee, because these concepts do not allow for the species' peculiarities. However, new developments in computational methods and increased computing capacity mean that it is now possible to apply these methods to honey bees. The reasons why most national breeding evaluation schemes now use the BLUP-Animal methodology are also relevant for the honey bee. In comparison to the widespread use of deviations from bee yard average or selection index (Bienefeld and Pirchner, 1991; van Engelsdorf and Otis, 2000) in honey bee evaluation, the described approach has two advantages:

\subsection{It considers the contribution from both castes on colony expression}

Selection based on a phenotype which has been insufficiently adjusted for the environmental effects of the bee yard also neglects the impact of queen and worker effects on the traits. Particularly in the case of negative correlation between maternal and direct effects, which is shown to exist in many 
species (Robinson, 1981), including the honey bee (Bienefeld and Pirchner, 1990), selection response is significantly reduced. A negative correlation between maternal and direct effects impedes selection response because it reduces the phenotypic variation and tends to keep the population at a particular value (Willham, 1963). Roehe and Kennedy (1993) demonstrated in a simulation analysis that selection response was reduced by up to $77 \%$ compared with the scenario in which maternal and direct effects were genetically independent.

\subsection{It considers genetic relatedness among colonies in order to facilitate genetic comparisons within the whole population}

The particularity of the (queen and worker) composed colony's character is not the only factor which is usually neglected. In most countries, selection in the honey bee is only based on environmentally adjusted phenotypic records. Usually, records are expressed as deviations from the bee yard average so that the influence of environment and beekeeping management can be removed. This seems to facilitate a fair comparison between queens from different bee yards/regions. One problem with deviations from bee yard average arises from the small size of the bee yards in which most colonies are kept. An average based on a few records is less reliable than one from a large number of colonies. More serious, however, is the ignoring of genetic differences among bee yards. As in individual records, these averages are influenced by the environment and the genotypes of the colonies involved. Consequently, deviations cannot be compared across bee yards or regions. Even a negative deviation in a bee yard with a superior genetic level may imitate a much more suitable genotype than a colony with a high positive deviation estimated in a poor genetic background. Modern methods of genetic evaluation, especially the BLUP-Animal model, provide for comparison across bee yards and regions. The evaluation makes use of "genetic links" created through cross-regional use of father colonies and through the distribution and testing of sister colonies at different testing stations. Since the BLUP-Animal Model approach considers the performances of the animal itself, all its relatives and the genetic values of the other colonies tested in each bee yard (genetic background), its estimates provide a much more reliable selection tool across the population. However, its exact relative efficiency depends on the genetic interlinking within the population.

To summarise, the following advantages of the BLUP-Animal Model methodology can be achieved by replacing traditional methods of breeding evaluation:

- It uses information available on all the relatives, optimally weighted depending on the genetic distance from the actual individual.

- It weights the information depending on its accuracy of comparison (size of testing station).

- It accounts for the selective use of animals by adjusting for the genetic merit of their mates.

- It accounts for the genetic competition between animals within a testing station.

- It corrects for culling as it occurs over time.

- It continually updates the breeding value as more information becomes available.

- It simultaneously corrects for all known environmental effects and for possible genetic differences between testing locations.

The above-described approach has been used in Germany since 1994 for estimation of breeding values in the honey bee. We found a selection response for honey production of $0.04 \%$ per year before initiating genetic evaluation (based on 37220 records). Since the BLUP-Animal model has been used for genetic evaluation, the increase (29214 records) was estimated as $0.54 \%$ per year, or 13 -fold higher. The selection response for the trait defensive behaviour increased from $0.03 \%$ (before) to $0.62 \%$ (since genetic evaluation) per year (Bienefeld, 2005). The BLUP-Animal Model represents a state-of-the-art methodology for the genetic evaluation of all other agricultural species (Mrode, 1996). The described modification of this approach permits 
the successful application of this most advanced technique to the honey bee as well.

\section{ACKNOWLEDGEMENTS}

The development of the software was funded by the Ministry of Agriculture of Brandenburg, Saxony, Saxony-Anhalt, Thuringia, the Senate for Economics and Technology in Berlin and the Deutsche Imkerbund (D.I.B.).

Évaluation de la valeur génétique de l'Abeille domestique du point de vue des effets de la reine et des ouvrières - une approche par le modèle animal BLUP.

Apis mellifera / valeur génétique / consanguinité / effet maternel / production de miel / modèle animal BLUP

Zusammenfassung - Zuchtwertschätzung bei der Honigbiene unter Berücksichtigung von Königinnen- und Arbeiterinneneffekten - Ein BLUP-Animal-Model-Ansatz. Die Zuchtwertschätzung ist bei der Honigbiene aus mehreren Gründen schwieriger als bei anderen landwirtschaftlichen Nutztieren. Volkseigenschaften sind bei der Honigbiene Ausdruck der gemeinsamen Aktivitäten der Königin und der Arbeiterinnen. Neuere Untersuchungen zeigten zudem noch eine negative genetische Korrelation zwischen den beiden Kasteneinflüssen bei Honigleistung und Verhalten der Völker. Dies muss bei der Selektion berücksichtigt werden, um den genetischen Fortschritt $\mathrm{zu}$ optimieren. Um das $\mathrm{zu}$ bewerkstelligen, wurde das aktuellste in der Tierzucht verwendete Zuchtwertschätzverfahren (BLUP-Animal Model) an die Besonderheiten der Honigbiene angepasst. Bei diesem Ansatz werden der genetische Einfluss der Königin und der Arbeitsbienen auf die Volkseigenschaften simultan berïcksichtigt und zur Berechnung des jeweiligen Zuchtwertes alle Prüfabschlüsse von verwandten Völkern verwendet, gewichtet mit dem genetischen Verwandtschaftsgrad zum jeweiligen Probanden. Ein wesentlicher Aspekt der Anpassung des Zuchtwertschätzkonzeptes an die Gegebenheiten der Honigbiene ist die Entwicklung einer veränderten Routine zur Berechnung der Verwandtschaftsmatrix, die zur genetische Verknüpfung aller Individuen (Königinnen und Durchschnittsarbeitsbienen) innerhalb der gesamten Population im Schätzmodell benötigt wird. Hierdurch wird jedes Volk als Informant für verwandte Völker genutzt und profitiert von allen Prüfergebnissen verwandter Völker bei der Berechnung seines Zuchtwertes. Darüber hinaus berücksichtigt die vorgeschlagene Methode simultan die quantifizierbaren Umweltfaktoren, das genetische Niveau der Anpaarungspartner und das der Vergleichstiere auf den Prüfständen. Dies ermöglicht eine sehr präzise und überregionale Bewertung des genetischen Potentials von Königinnen, die bei den bisher verwendeten Ausleseverfahren nicht möglich war.

Bienenzucht / Zuchtwertschätzung / Inzucht / Maternale Effekte / Genetischer Fortschritt / Apis mellifera

\section{REFERENCES}

Bienefeld K. (1994) Genetic characteristics of the honeybee (Apis mellifera) favour recurrent selection, Proc. 5th World Congr. Genet. Appl. Livestock Prod. 19, 115-118.

Bienefeld K. (2005) Deutliche Erfolge nach zehn Jahren Zuchtwertschätzung, Dtsch. Bienen J. 13, 244-246.

Bienefeld K., Pirchner F. (1990) Heritabilities for several colony traits in the honeybee (Apis mellifera carnica), Apidologie 21, 175-183.

Bienefeld K., Pirchner F. (1991) Genetic correlations among several colony characters in the honey bee (Hymenoptera: Apidae) taking queen and worker effects into account, Ann. Entomol. Soc. Am. 84, 324-331.

Bienefeld K., Reinhardt F. (1995) A new concept for calculation breeding values in the honeybee, Proc. 34. Int. Apimondia Congr., Lausanne, Apimondia Publishing House, Bucharest, pp. 9699.

Bienefeld K., Reinhardt F., Pirchner F. (1989) Inbreeding effects of queen and workers on colony traits in the honeybee, Apidologie 20, 439-450.

Böger K. (1969) Zur Selektion von Bienenvölkern auf Sammelleistung, Z. Bienenforsch. 9, 545-571.

Cale G.H., Rothenbuhler W.C. (1975) Genetics and breeding of the honey bee, in: Dadant and Sons (Ed.), The hive and the honeybee, Dadant and Sons, Hamilton, Illinois, pp. 157-184.

Chevalet C., Cornuet J.M. (1982) Étude théorique sur la sélection du caractère "production de miel" chez l'abeille. I. Modèle génétique et statistique, Apidologie 13, 39-65.

Chevalet C., Cornuet J.M. (1987) Étude théorique sur la sélection du caractère "Production de miel" chez l'abeille. II. Plan de sélection combinée de reines en fécondation naturelle, Apidologie 18, 254-266.

Crow J.F., Roberts W.C. (1950) Inbreeding and homozygosis in bees, Genetics 35, 612-621.

Dempfle L. (1989) Problems in the use of the relationship matrix in animal breeding, in: Gianola D., Hammond K. (Eds.), Advances in Statistical Methods for Genetic Improvement of Livestock, Springer Verlag, pp. 454-473. 
Foulley J.L., Lefort G. (1978) Méthodes d'estimation des effects directs et maternels en sélection animale, Ann. Genet. Sel. Anim. 10, 475-496.

Hanrahan J.P. (1976) Maternal effects and selection response with application to sheep data, Anim. Prod. 22, 359-369.

Harbo J.R. (1996) Evaluating colonies of honey bees for resistance to Varroa jacobsoni, BeeScience 4, $100-105$.

Henderson C.R. (1976a) A simple method for computing the inverse of a numerator relationship matrix used in prediction of breeding values, Biometrics $32,69-83$.

Henderson C.R. (1976b) Inverse of a matrix of relationship to sires and maternal grandsires in an inbred population, J. Dairy Sci. 59, 1585-1588.

Henderson C.R. (1988) Theoretical basis and computational methods for a number of different animal models, J. Dairy Sci. 71, 1-16.

Kulincevic J.M. (1986) Breeding Accomplishments with Honey Bees, in: Rinderer T.E. (Ed.), Bee Genetics and Breeding, Academic Press, London, pp. 391-413.

Laidlaw H.H., Page R.E. (1984) Polyandry in honey bees (Apis mellifera L.): Sperm utilization and intracolony genetic relationship, Genetics 108, 985997.

Lerner I.W. (1950) Population genetics and animal improvement, Cambridge University Press, Cambridge.

Mackensen O., Nye W.P. (1966) Selecting and breeding honey bees for collecting alfalfa pollen, J. Apic. Res. 5, 79-86.

Milne C.P. (1985) The need for using laboratory tests in breeding honeybees for improved honey production, J. Apic. Res. 24, 237-242.

Moritz R.F.A. (1986) Comparison of within-family and mass selection in honeybee populations, J. Apic. Res. 25, 146-153.

Mrode R.A. (1996) Linear models for the prediction of animal breeding values, CAB International, Wallingford, UK.

Oldroyd B.P., Moran C., Nicholas F.W. (1985) Diallel crosses of honeybees 1. A genetic analysis of honey production using a fixed effects model, $\mathrm{J}$. Apic. Res. 24, 243-249.

Page R.E., Laidlaw H.H. (1982) Closed population honeybee breeding. 2. Comparative methods of stock maintenance and selective breeding, J. Apic. Res. 21, 38-44.

Polhemus M.S., Lush J.L., Rothenbuhler W.C. (1950) Mating systems in honeybees, J. Hered. 41, 151-154.

Quaas R.J., Pollak E.J. (1981) Modified equations for sire models with groups, J. Dairy Sci. 64, 18681872 .

Rinderer T.E. (1977) A new approach to honey bee breeding at the Baton Rouge USDA, Laboratory, Am. Bee J. 117, 146-147.

Robinson O.W. (1981) The influence of maternal effects on the efficiency of selection: A review, Livest. Prod. Sci. 8, 121-137.

Roehe R., Kennedy B.W. (1993) The influence of maternal effects on accuracy of evaluation of litter size in swine, J. Anim. Sci. 71, 2353-2364.

Ruttner F. (1968) Methods of breeding honeybees: Intra-racial selection or inter-racial hybrids? Bee World 49, 66-72.

Szabo T.I., Lefkovitch L.P. (1987) Fourth generation of closed-population honeybee breeding 1 . Comparison of selected and control strains, J. Apic. Res. 26, 170-180.

Van Engelsdorf D., Otis C.W. (2000) Application of a modified selection index for honey bees (Hymenoptera Apidae), J. Econ. Entomol. 93, 1606-1612.

Willam A. (1991) Parameter- und Zuchtwertschätzung für die Honigbiene (Apis mellifera carnica), $\mathrm{Ph} . \mathrm{D}$. Thesis, University of Agricultural Sciences, Vienna.

Willham R.L. (1963) The covariance between relatives for characters composed of components contributed by related individuals, Biometrics 19, 1827.

Wright S. (1922) Coefficients of inbreeding and relationship, Am. Nat. 56, 330-338. 